\title{
The Experiences of Violence and Occupational Health Risks of Sex Workers Working in Brothels in Ankara
}

\author{
Aysun Balseven Odabaşı1, Serap Şahinoglu², Yasemin Genç33, Yaşar Bilge ${ }^{4}$ \\ 'Department of Forensic Medicine, Faculty of Medicine, Hacettepe University, Ankara, Turkey \\ ${ }^{2}$ Department of Medical History and Ethics, Faculty of Medicine, Ankara University, Ankara, Turkey \\ ${ }^{3}$ Department of Biostatistics, Faculty of Medicine, Ankara University, Ankara, Turkey \\ ${ }^{4}$ Department of Forensic Medicine, Faculty of Medicine, Ankara University, Ankara, Turkey
}

\begin{abstract}
Objective: The aim of this study was to reveal and discuss occupational health risks, violence against sex workers working in brothels and their working conditions in Ankara.

Materials and Methods: The study included 138 sex workers. Data were collected at face to face interviews with a questionnaire composed of 40 questions about socio-demographic features, familial characteristics, reasons for becoming a sex worker, experiences of violence and occupational health risks.

Results: Twenty-two point five percent of the women were aged $21-30$ years and $39.9 \%$ were aged $31-40$ years. The mean time of education was $5.9 \pm 3.5$ $(0-14)$ years. Forty-eight point five percent of the women were exposed to physical abuse and $13 \%$ of the women had been exposed to sexual abuse in their childhood. Fifty-five point eight percent of the women reported that their clients always used condoms, but $97.1 \%$ of the women noted that their clients insisted on not using a condom. Fourteen point five percent and $70.3 \%$ of the women were exposed to physical and verbal violence respectively from their clients. Ten point one percent of the women suffered sexual assault while working.
\end{abstract}

Conclusion: Sex workers, like other people, should have human rights, all types of violence that they face should be eliminated and the social conditions they are exposed to should be improved. Sexually transmitted diseases, the most important health risk of sex workers, should be considered as occupational diseases in the new regulations.

Key Words: Prostitution, sex worker, violence against woman, human rights, sexual transmitted diseases

\section{Introduction}

Sex work is considered as a threat to public health, public order, decency, economy, safety and women's rights (1). Sex workers in most countries are stigmatized, exposed to discrimination and sexual abuse and prosecuted (2).

Sex workers in Turkey, like those in other countries, are outlawed by society, they and their problems are ignored and their health is cared for only to prevent diseases in their clients and the public, but not to protect their health.

There are 56 licensed brothels with about 3,000 sex workers in these brothels in Turkey. It has been reported that there are about 100,000 female and transgender sex workers in Turkey. Thousands of sex workers work in the streets, brothels, massage parlours, bars, night clubs, and even on buses and minibuses, mainly in İstanbul and Ankara (3).

Regulations for sex work in Turkey are directed only towards the working conditions of registered female sex workers working in brothels. The only regulation for sex workers working in brothels and their working conditions is the Stat- ute of Brothels and Brothel Women and Prevention of Sexually Transmitted Diseases, which was put into effect in 1961 and which is still in effect. According to this statute, women have to be at least 21 years old and Turkish citizens to work in brothels. They also have to be examined in a Skin and Sexually Transmitted Diseases Hospital twice a week (4).

Sex work has many occupational health risks. Sex workers suffer from verbal and physical violence, are exposed to sexual assault and have to work in unsafe places. Sex workers working in brothels account for the overwhelming majority of sex workers. Therefore, we aimed to investigate the occupational risks, violence and working conditions which sex workers in brothels are exposed to in Turkey and to discuss them in the light of the available literature.

There have been few studies on the health status of sex workers, their relationships with society and experience of violence. This can be attributed to the difficulty in contacting sex workers. We also had difficulty in accessing sex workers and therefore, we had to select sex workers working in the brothels and visiting the Skin and Sexually Transmitted Diseases Hospital in Ankara for screening.

$8^{\text {th }}$ International Congress of Feminist Approaches to Bioethics Abstract Book, page: 23. Singapure, 26-28 July 2010.

Address for Correspondence: Dr. Aysun Balseven Odabaşı, Department of Forensic Medicine, Faculty of Medicine, Hacettepe University, Ankara, Turkey Phone: +90312305 2004 E-mail: balseven@hacettepe.edu.tr 


\section{Material and Methods}

This study was conducted in the Skin and Sexually Transmitted Diseases Hospital in Ankara. The hospital's primary clients are registered sex workers. Approximately 200 registered sex workers make regular visits to this hospital annually. According to Turkish laws, all registered prostitutes in the area must make regular visits to this hospital to be screened for gonorrhea, syphilis and AIDS. When women first apply for sex work, they undergo tests for hepatitis B and are vaccinated if they need it. Cervical cultures are obtained and a test for gonorrhea is performed twice a week and a syphilis test and an AIDS test are made every three months for all registered sex workers. The results of each visit are recorded.

The study included 138 out of 174 female sex workers attending the Skin and Sexually Transmitted Diseases Hospital for their routine examinations and volunteering to participate in the study. Written informed consent was obtained from all the participants and data were collected with a questionnaire at face to face interviews between April 2007 and August 2007. Approval was obtained from the ethics committee of the Medical School of Gazi University.

The questionnaire was composed of 40 questions about socio-demographic features, familial characteristics, reasons for becoming a sex worker and occupational health risks.

\section{Statistical analysis}

Depending on the type of variables tested, Pearson's Chisquare test or Mantel-Haenszel Chi-square test was used to determine the difference/relation between variables used to define demographic characteristics, sex work background and experience and occupational health risks which the women faced. Pearson's chi-square test $\left(\chi^{2}\right)$ was used to determine the difference between two nominal variables. Mantel-Haenszel Chi-square $\left(\mathrm{MH} \chi^{2}\right)$ test was used to determine the linear relation between two ordinal variables. Gamma was used to assess associations between two ordinal variables. Gamma, also called Goodman and Kruskal's Gamma, is a symmetric measure which varies from -1 to +1 , based on the difference between concordant pairs and discordant pairs. Spearman's rho correlation coefficient was used to determine the correlation between two rank-ordered scales.

\section{Results}

The study included 138 out of 174 female sex workers attending the Skin and Sexually Transmitted Diseases Hospital for their routine examinations and volunteering to participate in the study. Missing responses in the questionnaire were not included in the statistical analysis.

\section{Demographic characteristics}

Thirty-nine point nine percent of the women were aged between 31-40 years. Twelve point three percent of the women had not even attended primary school, $7.2 \%$ were primary school dropouts, $43.5 \%$ were primary school graduates and $37 \%$ of the women had a higher level of education. Sixty point one percent of the women were from urban areas and
$39.9 \%$ were from rural areas. Sixty-two point nine percent of the women were divorced and $69.3 \%$ had children. Forty-five point two percent of the women came from families with a low socio-economic status (Table 1).

\section{Sex work background and experience}

Forty-seven point eight percent of the women had a work experience of 1-10 years. The mean age of first sexual intercourse was $16.3 \pm 3.2(10-22)$ years (Table 2$)$ and $34.6 \%$ of the women had their first sexual intercourse before the age of

Table 1. Demographic characteristics of sex workers working in brothels in Ankara

\begin{tabular}{|c|c|}
\hline Demographic characteristics & n (\%) \\
\hline \multicolumn{2}{|l|}{ Age, $(n=138)$} \\
\hline $21-30$ years & $31(22.5)$ \\
\hline $31-40$ years & 55 (39.9) \\
\hline $41-50$ years & $36(26.1)$ \\
\hline 51 years and over & $16(11.6)$ \\
\hline \multicolumn{2}{|l|}{ Education, $(n=138)$} \\
\hline Never attended primary school & $17(12.3)$ \\
\hline Primary school drop out & $10(7.2)$ \\
\hline Primary school graduates & $60(43.5)$ \\
\hline \multicolumn{2}{|c|}{ Women with a higher level of education 51 (37.0) } \\
\hline \multicolumn{2}{|c|}{ Place where raised, $(n=138)$} \\
\hline Rural & 55 (39.9) \\
\hline Urban & $83(60.1)$ \\
\hline \multicolumn{2}{|l|}{ Marital status, $(n=135)$} \\
\hline Single & $34(25.2)$ \\
\hline Divorced & $85(62.9)$ \\
\hline Widowed & 16 (11.9) \\
\hline \multicolumn{2}{|l|}{ Children, $(n=137)$} \\
\hline No & $42(30.7)$ \\
\hline Yes & $95(69.3)$ \\
\hline \multicolumn{2}{|l|}{ Families' economic status, $(n=135)$} \\
\hline Low & $61(45.2)$ \\
\hline Moderate & $57(42.2)$ \\
\hline High & $17(12.6)$ \\
\hline
\end{tabular}

Table 2. Sex work background and experience of sex workers working in brothels in Ankara

\begin{tabular}{|lc|}
\hline Sex work background and experience & $\mathbf{n}(\%)$ \\
\hline Work in prostitution, $(\mathrm{n}=138)$ & \\
$1-10$ years & $66(47.8)$ \\
$11-20$ years & $52(37.7)$ \\
21 years and over & $20(14.5)$ \\
First sexual intercourse, Mean \pm SD & $16.3 \pm 3.2(10-22)$ \\
(Min-Max) & \\
\hline SD: Standard Deviation & \\
\hline
\end{tabular}


15. Sixty point one percent of the women had their first intercourse unwillingly.

There was a significant relation between their age at first sexual intercourse and education and as the duration of education increased, so did their age at first sexual intercourse $(r=0.339, p<0.001)$

\section{Occupational health risks}

The primary risk factors are problems with condom use, sexually transmitted diseases (STD), alcohol and tobacco use and frequent abortion.

Concerning the question "How often do the clients use condoms?", $55.8 \%$ of the women noted that the clients always use condoms, $97.1 \%$ of the women reported that the clients do not want to use condoms and $89.1 \%$ of the women reported that the clients offer more money in order not to use condoms. Eighteen point two percent and $63.8 \%$ of the women were exposed to physical and verbal violence respectively when they asked the clients to use condoms (Table 3). There was a significant relation between age and condom use $\left(\mathrm{MH} \chi^{2}=6.3, \mathrm{p}=0.012\right)$. As age increased, condom use significantly decreased (Gamma=- 0.303, $p=0.005$ ). There was a significant relation between age and verbal violence due to requests for condom use $\left(\mathrm{MH} \chi^{2}=6.6, \mathrm{p}=0.010\right)$. As age increased, the frequency of verbal violence significantly decreased (Gamma $=-0.272, p=0.012$ ). There was a significant relation between the place where the women were raised and frequency of condom use. The women from urban areas used condoms more frequently than those from rural areas $\left(\chi^{2}=7.5, p=0.006\right)$. There was a significant relation between the frequency of condom use and work experience. As the duration of work experience increased, the frequency of condom use significantly decreased (Gamma=-0.277, $p=0.020$ ). Thirty-five point five percent of the women noted that they had STD. Thirty-five point five percent of the women had had many abortions. There was a significant relation between education and the frequency of abortion $\left(\mathrm{MH} \chi^{2}=11.0, \mathrm{p}=0.001\right)$. As education increased, the frequency of abortion significantly decreased (Gamma $=-0.386, p=0.001$ ). There was a significant relation between sex work duration and the frequency of abortion ( $\left.\mathrm{MH} \chi^{2}=4.8, \mathrm{p}=0.029\right)$. As the sex work background increased, so did the frequency of abortion (Gamma=0.240, $p=0.023)$. There was a significant relation between marital status and physical violence due to the request for condom use. Widowed women suffered from more violence than divorced women $\left(\chi^{2}=13.6, p=0.009\right)$. Forty-eight point five percent seven percent of the women were smokers, $55.1 \%$ were using alcohol and $2.8 \%$ were using other substances (Table 3 ).

\section{Gender-based violence}

\section{Childhood physical and sexual abuse}

Forty-eight point five percent and 13\% of the women noted that during their childhood they had suffered physical violence and sexual abuse respectively. Twenty-seven point seven percent of the women exposed to sexual violence did not answer the question "Who abused you sexually?", 33.3\% admitted that their close relatives sexually abused them and $22.2 \%$ reported that their stepfather abused them.
Table 3. Occupational health risks of sex workers working in brothels in Ankara $(n=138)$

\begin{tabular}{|cc|}
\hline Occupational health risks & $\mathbf{n}(\%)$ \\
\hline Condom use & \\
Sometimes & $24(17.4)$ \\
Mostly & $37(26.8)$ \\
Always & $77(55.8)$
\end{tabular}

Clients' insistence on not using condoms

Yes

$134(97.1)$

No

Offered extra money for sex without condom

Yes

No

Physical violence due to request for condom use

Never

Sometimes

Always or mostly

Verbal violence due to request for condom use

Never

Sometimes

Always or mostly

Sexually Transmitted Diseases (STDs)

Suffering from STDs

Yes

No

Frequency of abortion

None

Once

A few times

Many times

Substance use

Cigarette smoking

Yes

No

Alcohol intake

Yes

No

Drug use

Yes

No

$134(97.1)$

\section{Sex work related violence}

Fourteen point five percent of the women reported that they were exposed to physical violence by their clients and $70.3 \%$ noted that they were exposed to verbal and emotional violence by their clients (Table 4). There was a significant relation between age and client violence $\left(\mathrm{MH} \chi^{2}=8.4, \mathrm{p}=0.004\right)$. 
As age increased, the frequency of client violence significantly decreased (Gamma=-0.572, $p=0.002$ ). There was also a significant relation between a sex work background and client violence $\left(\mathrm{MH} \chi^{2}=4.5, \mathrm{p}=0.035\right)$. As the sex work background increased, the frequency of client violence significantly decreased (Gamma=-0.516, $\mathrm{p}=0.007$ ). Ten point one percent percent of the women suffered from sexual assault. Thirty-four point one percent of the women had a history of suicide attempts. In fact, $51.1 \%$ of the women had made one suicide attempt, $36.2 \%$ had made several suicide attempts and $12.8 \%$ had made many suicide attempts (Table 4). Cross match statistics are shown in Table 5.

\section{Discussion}

Sex workers included in this study were vulnerable to verbal and physical violence and sexual assault, experienced different types of violence and suffered from both physical and psychological damage due to the risks they faced.

The distribution of the women by age showed that $62.4 \%$ of the women were aged between $21-40$ years, which is consistent with the finding in the literature that most of the sex workers were young women (5-7). In addition, in Turkey the legal age for women to work in brothels is 21 . Therefore, none of the women included in this study were younger than 21 years.

Insufficient education is one of the most important factors predisposing to sex work. Gender discrimination is an important barrier to the education of women. At present, unemployment is a serious problem and unfortunately, women with insufficient education have difficulties in finding a job and tend to become sex workers. In the present study, the mean duration of education was $5.9 \pm 3.5(0-14)$ years, $12.3 \%$ of the women were illiterate and $43.5 \%$ of the women were primary school graduates. In a study by Simsek from Turkey of female sex workers working in brothels in $2003,45 \%$ of the women were primary school graduates and $24 \%$ of the women had no education. We performed the present study five years after the study by Simsek and revealed that, although the number of the women with no education decreased, there was no change in the number of the women receiving a five-year education. This indicates that the sex workers working in brothels still had insufficient education.

As for the duration of work experience, $14.5 \%$ of the women had work experience of over 20 years. This suggests that the women did not consider sex work as transient but a permanent occupation.

Physical and sexual abuses in childhood are risk factors to become sex workers. Shoham et al. emphasized that parental neglect, exposure to maltreatment and abuse in childhood played an important role in becoming prostitutes (8). Brawn and Roe-Sepowitz commented that low-socio economic status, familial violence, chaotic and insufficient familial relationships, experience of sexual intercourse early in life and sexual abuse were the main causes of prostitution (9). Many studies have revealed that sexual abuse in childhood and adolescence have negative impacts such as post traumatic stress disorder, depression and suicidal tendency in the short and long term and that there is a relation between early sexual intercourse,
Table 4. Childhood physical and sexual abuse, sex work related violence and sex work related suicide attempts of sex workers working in brothels in Ankara

\begin{tabular}{|cc|}
\hline Gender-based violence & $\mathbf{n}(\%)$ \\
\hline $\begin{array}{c}\text { Childhood physical and sexual abuse } \\
\text { Childhood physical abuse, }(\mathrm{n}=138)\end{array}$ \\
Never & $71(51.4)$ \\
A few times & $27(19.5)$ \\
Frequently & $40(29.0)$ \\
Sexual abuse, $(\mathrm{n}=138)$ & \\
Never & $120(87.0)$ \\
A few times & $10(7.2)$ \\
Frequently & $8(5.8)$
\end{tabular}

Sex work related violence

Physical violence by clients, $(n=138)$

Never

$118(85.5)$

A few times

Frequently

Emotional abuse by clients,

(verbal violence), $(n=138)$

Never

A few times

Frequently

History of sexual assault, $(n=138)$

Yes

No

$124(89.9)$

Sex work related suicide attempts

Suicide attempt (ever), $(n=138)$

Yes

No

Suicide attempt frequency, $(n=47)$

Once

A few times

Many times

$6(12.8)$

considered a risky sexual behavior, and becoming a sex worker (9-11).

Consistent with the literature, in the present study $48.5 \%$ of the women endured physical violence and $13 \%$ of the women had suffered from sexual abuse in childhood.

Economic conditions are another important factor leading to prostitution (12-14). In fact, $42.5 \%$ of the women included in the present study came from low-income families. Wong et al. (15) in a study of female sex workers in Hong Kong revealed that most of them worked to provide financial support for their families. Ward and Day in their study reported that most of the female sex workers had two choices: either poverty or sex work and that they took the risk of being a social outcast since the disadvantages of poverty outweigh those of sex work (1). 
Table 5. Cross match statistics

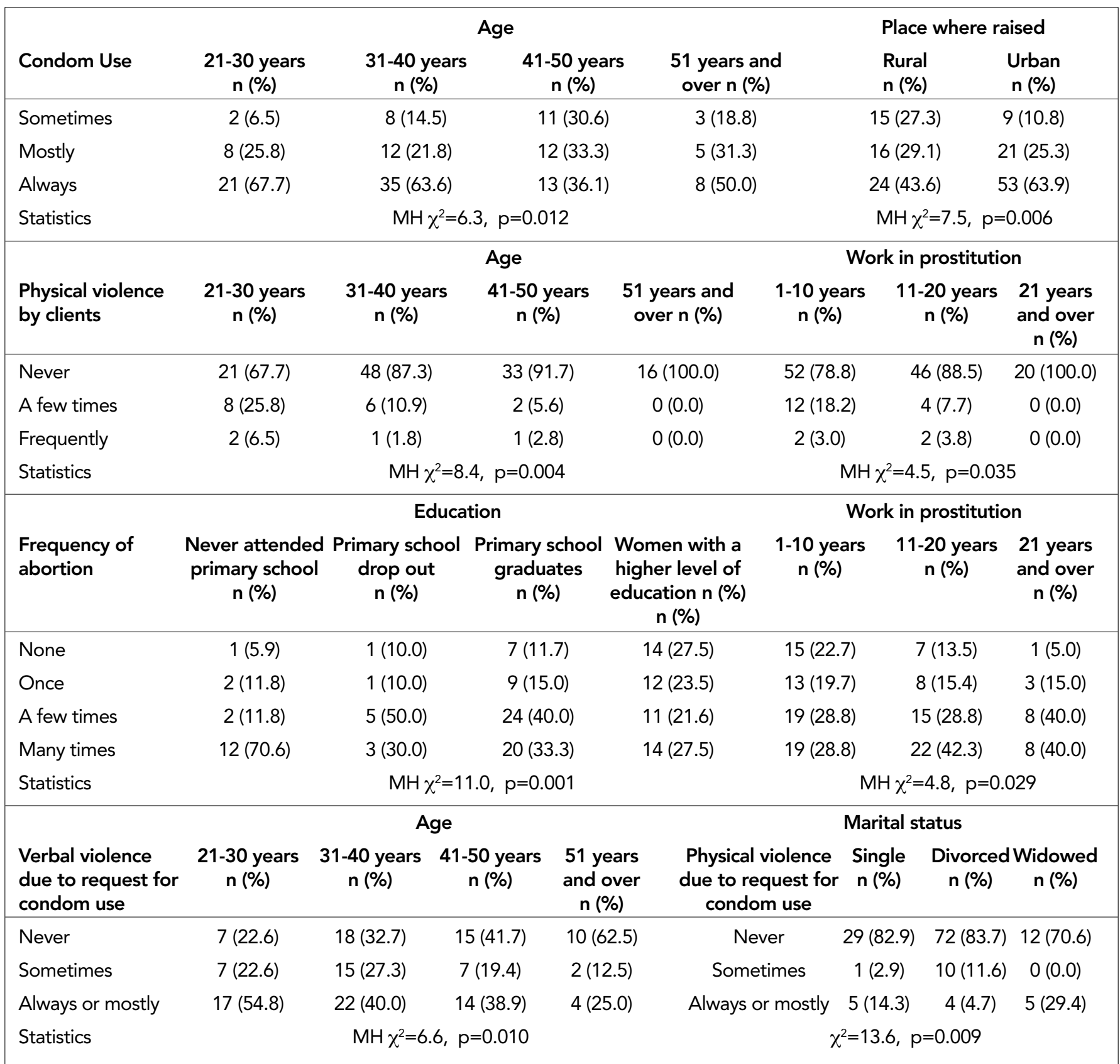

In the present study, the women had their first sexual intercourse at quite an early age. Thirty-four point six percent of the women had their first sexual intercourse before they were fifteen and the mean age of first sexual intercourse was $16.3 \pm 3.2$ years. Sixty point one percent of the women were raped in their first sexual intercourse. The women in Turkey generally do not exercise their right to refuse early marriage and, especially in rural areas, early marriages are traditionally favoured. Many women younger than 18 in the rural areas have religious marriage contracts. Most of the women having their first sexual intercourse unwillingly had that experience as a result of religious marriage contracts in childhood.

In the Sexual and Reproductive Health Study conducted by the Society for Sexual Education, Treatment and Research in 2006, values concerning sexuality and virginity were investigated. Sixty-three percent of the men completely agreed with the statement "virginity shows female decency" and 65\% of the men completely agreed with the statement "Women should remain virgins until they get married' (16).

In Turkey, sexual intercourse before marriage is not approved. Social stigma towards women having sexual intercourse before marriage and reactions from their families cause hopelessness in these women and make them feel that they have no other choice except sex work.

As for smoking and substance abuse, $87.7 \%$ of the women were smokers, $55.1 \%$ of the women were taking alcohol and $2.8 \%$ of the women were using other substances. In general, the women declined to answer the question about substance 
abuse. However, two women were using marihuana and two women were taking drugs. According to data from the Turkish Population and Health Survey in $2008,22 \%$ of the women aged 15-49 years were smokers (17). It is striking that the rate of the female sex workers who smoked was four times higher than that of the female smokers in the general population.

Nearly all studies on female sex workers have revealed that the women experience verbal, physical and psychological violence. In a study by Farley and Haling, $82 \%$ of the female sex workers suffered physical violence, $83 \%$ were threatened by their clients with guns, $68 \%$ had sexual assaults and $84 \%$ were homeless (18). Potterat et al. (19) reported that female sex workers were exposed to lethal and non-lethal violence by their clients. Lowman in a study in Canada between 1992 and 1998 , reported that 86 female sex workers were murdered and that the murderers of 16 women were clients, one was a procurer and nine were others (20).

Consistent with the literature, the female sex workers in this study reported their experiences with different types of violence. Thirty-nine point nine percent of the women had suffered physical violence from their intimate partners, $14.5 \%$ received physical violence from clients and $10.1 \%$ had suffered sexual assault.

STDs are the most important occupational risks for female sex workers. It has been shown that the rate of males having sex with sex workers in Turkey is high (21). In a study conducted in several big cities in the USA, 2-3\% of men were found to be clients of female sex workers on the streets during 2-5-year observations (22)

In the present study, concerning the questions "Which sexually transmitted diseases have you had and how often have you had them?", 49 women noted that they had STDs and 69 women noted that they never had STDs. Of 49 women having STDs, $36.7 \%$ had gonorrhea, $30.6 \%$ had syphilis and $16.3 \%$ had vaginitis.

During the one-year study period, 26 out of 174 women examined at the Skin and Sexually Transmitted Diseases Hospital had gonorrheal infection.

The most effective method of preventing STDs is the use of a condom. Client attitudes play an important role in the use of condoms. In a study of the use of condoms in sex workers and clients, the rate of the participants who knew about AIDS and used condoms increased over the years. In fact, $51 \%$ of the sex workers knew about AIDS between 1992 and 1993 and the rate increased to $97 \%$ in 1999 . In addition, the rate of sex workers using condoms was 19\% between 1992 and 1993 and increased to $78 \%$ in 1999 (23).

In the present study, $55.8 \%$ of the women responded "always" to the question "How often do clients use condoms?". This shows that about half of the women did not use condoms regularly. It may be that the women did not have sufficient information about STDs and could not refuse the money offered by their clients for sex without condoms. In addition, isolated, discriminated, despised and deprived of their rights, these women might have disregarded the risk of diseases.

Ninety-seven point one percent of the women noted that clients did not want to use condoms and $89.1 \%$ of the women reported that clients offered money in order not to use con- doms. This causes an unfair competition between the women working as sex workers due to financial difficulties. The women commented that when they insisted on using condoms, the clients who did not want to use condoms preferred the women accepting unprotective sex. Especially the older women with fewer clients agreed to have sex without condoms for financial reasons.

In a study of immigrant sex workers in Europe, clients were found to agree to pay more in order not to use condoms, which created a higher risk especially for immigrant sex workers. It is thought that these sex workers more frequently took risks due to financial reasons (24). In the present study, $18 \%$ and $63.8 \%$ of the women were exposed to physical and verbal violence respectively since they asked clients to use condoms.

III-health refers to both physical and mental illnesses $(25,26)$. It is known that sex workers are isolated from society $(14,27)$. Sex workers are exposed to poor health conditions including physical threats. It has been reported that the rate of the sex workers suffering from violence while working varies from $35 \%$ to $94 \%(27,28)$. Romans et al. (29) found no difference in physical health between sex workers and the general population. There have been no comparative studies on the health status of female sex workers working in brothels and street sex workers in Turkey. In the present study, concerning chronic health problems, $13.8 \%, 5.1 \%$ and $2.9 \%$ of the women suffered from hypertension, diabetes and depression respectively.

Thirty-four point one percent of the women noted that they had made one, a few or many suicidal attempts. Okman reported that $1.8 \%$ of women in Turkey committed suicide (30). The high rate of suicides in our study can be attributed to the poor mental health status of these women. A study of various groups of sex workers female brothel workers, private sole-operators and female street sex workers in Australia and New Zealand showed no difference in physical health problems between these groups, but revealed that scores on poor mental health were four times higher among the women working illegally. It may be that these women might have already had a poor mental health status before becoming a sex worker and that the higher risk factors related to sex work might have affected their mental health (27).

\section{Conclusion}

Sex workers are at the highest risk of STDs. They are incriminated for spreading STDs in society. They are cast out from the society to protect public health, they have to work under poor health conditions and they mostly are not given the chance to have a healthy sexual relationship. Although sex workers are screened for STDs at every turn on the basis of the idea that they spread STDs, the clients' role in the spread of these diseases is disregarded.

STDs, one of the most serious health risks of sex workers, should also be considered as an occupational health disease. In Turkey, occupational infectious diseases in the Statute of Social Insurance Health Processes are divided into four, and the expression "people having contact with infectious diseases due to their profession" in the fourth group probably 
refers to health professionals. The Health Council of the Social Insurance Institution decides whether a disease not listed in the statue is an occupational disease and whether patients with occupational diseases should be offered treatment when the Social Insurance Institution is no longer responsible for it. Therefore, occupational infectious diseases suffered by sex workers should be incorporated into the list of occupational diseases by the Health Council of Social Insurance Institution. If sex workers are considered as employed and eligible for insurance, STDs acquired by them at work can be categorized as occupational diseases.

New regulations should be made so that diseases such as cervical cancer due to HPV and HIV contracted after they start work can be considered as occupational diseases. Thus, sex workers found on their regular follow-ups to have contracted these diseases can benefit from the rights offered to other employees in the statute.

Total disregard for sex workers' rights and the screening of sex workers for STDs just to protect public health increase their feeling of being outcasts. Sex workers, like other people, should have human rights, all types of violence they face should be eliminated, the social conditions they are exposed to should be improved, their financial status should be improved and their right to retire should be safeguarded. New regulations including all these improvements should be adopted.

\section{Conflict of Interest}

No conflict of interest was declared by the authors.

\section{References}

1. Ward H, Day S. What happens to women who sell sex? Report of a unique occupational cohort. Sex Transm Infect 2006;82:413-7. [CrossRef]

2. Wolffers I, Belen N. Public health and the human rights of sex workers. The Lancet 2003;361:1981. [CrossRef]

3. Kuntay E, Cokar M. Cinsel saglık ve ureme sagligi alaninda ulusal ve yerel medya yoluyla savunuculuk projesi, Bilgilendirme Dosyasi 8: Seks Ticareti, Cinsel Egitim Tedavi ve Arastirma Dernegi Yayinlari, İstanbul 2007.

4. http://www.mevzuat.adalet.gov.tr/html/5189.html

5. Dandona R, Dandona L, Kumar GA, Gutierrez JP, McPherson S, Samuels F, et al. ASCI FPP Study Team. Demography and Sex Work Characteristics of Female Sex Workers in India. BMC Int Health Hum Rights 2006;14:5. [CrossRef]

6. Buckingham RW, Moraros J, Bird Y, Meister E, Webb NC. Factors Associated with Condom Use Among Brothel-Based Female Sex Workers in Thailand. AIDS Care 2005;17:640-7. [CrossRef]

7. Simsek S, Kisa A, Dziegielewski SF. Sex workers and the issues surrounding registration in Turkey. J Health Soc Policy 2003;17:55-69. [CrossRef]

8. Shoham SG, Rahav G, Markovski R, Ber I, Chard F, Rachamin Y et all. Family variables and stigma among prostitutes in Israel. J Soc Psychol 1983;120:57-62. [CrossRef]

9. Brawn KM, Roe-Sepowitz D. Female juvenile prostitutes: exploring the relationship to substance use. Child Youth Serv Rev 2008;30:1395-402. [CrossRef]
10. Beitchman JH, Zucker KJ, Hood FE, Dacosta GA, Cassavia E. A review of the long-term effects of child sexual abuse. Child Abuse Negl 1992;16:101-18. [CrossRef]

11. Senn TE, Carey MP, Vanable PA. Childhood and adolescent sexual abuse and subsequent sexual risk behavior: Evidence from controlled studies, methodological critique, and suggestions for research. Clin Psychol Rev 2008;28:711-35. [CrossRef]

12. Do Espirito Santo ME, Etheredge GD. And then I became a prostitute. Some aspects of prostitutes in Dakar, Senegal. Soc Sci J 2004;41:137-46. [CrossRef]

13. Sieberg KK. Prostitution. Criminal dilemmas, Understanding and Preventing Crime, Springer Pub. Second Ed., Germany 2005, p. 49-74.

14. Dalla R. Exposing the "Pretty Woman" myth: a qualitative examination of the lives of female streetwalking prostitutes. J Sex Res 2000;37:344-53. [CrossRef]

15. Wong W, Holroyd E, Gray A, Ling D. Female street sex workers in Hong Kong: moving beyond sexual health. J Women Health 2006;15:390-9. [CrossRef]

16. Karabey $\mathrm{S}$, Muftuoglu N. Cinsel sağlık ve üreme sağlığı alanında ulusal ve yerel medya yoluyla savunuculuk projesi, Cinsel Eğitim Tedavi ve Araştırma Derneği Bilgilendirme Dosyası 2007;26-29.

17. Hacettepe Üniversitesi Nüfus Etütleri Enstitüsü, Türkiye Nüfus ve Sağlık Araştırması, 2008, Hacettepe Üniversitesi Nüfus Etütleri Enstitüsü, Sağlık Bakanlığı Ana Çocuk Sağlığı ve Aile Planlaması Genel Müdürlüğü, Başbakanlık Devlet Planlama Teşkilatı Müşteşarlığı ve TÜBiTAK, Ankara, Türkiye 2009.

18. Farley $M$, Haling N. Prostitution, violence and posttraumatic stress disorder. Women \& Health 1998;27:37-49. [CrossRef]

19. Potterat JJ, Brewer DD, Muth SQ, Rothenberg RB, Woodhouse $D E$, Muth JB, et al. Mortality in a long-term open cohort of prostitute women. Am J Epidemiol 2004;159:778-85. [CrossRef]

20. Lowman J. Violence and the outlaw status of (street) prostitution in Canada. Violence Against Women 2000;6:987-1011. [CrossRef]

21. Akın L. Türkiye'de cinsel yolla bulaşan enfeksiyonların epidemiyolojisi. Türkiye Klinikleri J Med Sci 2006;26:655-65.

22. Brewer DD, Roberts JM, Muth SQ, Potterat JJ. Prevalence of male clients of street prostitute women in the United States. Hum Organ 2008;67:346.

23. Ford K, Wiraman DN. Condom use among brothel-based sex workers and clients in Bali, Indonesia. Sex Health 2005;2:89-96. [CrossRef]

24. Mardh PA, Genc M. Migratory prostitution with emphasis on Europe. J Travel Med 1995;2:28-32. [CrossRef]

25. Boyd C. Customer violence and employee health and safety. Work, Employment \& Society 2002;16:151-69. [CrossRef]

26. Lindblom K, Linton S, Fedeli C, Bryngelsson I. Burnout in the working population: Relations to psychosocial work factors. Int J Behav Med 2006;13:51-9. [CrossRef]

27. Seib C, Fischer J, Najman J. The Health of female sex workers from three Industry sectors in Queensland, Australia. Social Science \& Medicine 2009;68:473-8. [CrossRef]

28. Church S, Henderson M, Barnard M, Hart G. Violence by clients towards female prostitutes in different work settings: questionnaire survey. Br Med J 2001;322:524-5. [CrossRef]

29. Romans S, Potter K, Martin J, Herbison P. The mental and physical health of female sex workers: A comparative study. Aust N Z J Psychiatry 2001;35:75-80. [CrossRef]

30. Okman T. Türkiye'de intihar istatistiklerinin metodolojisi, sistemi ve egilimi, Kriz Dergisi 1997;5:43-57. 